\title{
GENETICAL AND ENVIRONMENTAL FACTORS AFFECTING SLAUGHTER TRAITS IN BEEF PRODUCTION EXPERIMENTS IN FIELD
}

\author{
HILKKA KENTTÄMIES
}

University of Helsinki, Department of Animal breeding, $00710 \mathrm{Helsinki}$

\begin{abstract}
During the years 1971-77 the carcass weight of fattening calves delivered from dairy herds increased by $40 \mathrm{~kg}$. During the same period the differencies between areas grew smaller. The growth rate and carcass traits were affected by feed type of the farm, rearing time, sex of the calf and breed of sire. In comparison with the Ayrshire bulls, the carcass weight of contemporary Charolais bulls was 16 and of Friesian $12 \%$-units higher, but of Finncattle bulls $7 \%$-units lower. Differencies between heifers were still larger. The growth rate of $\mathrm{Ch}$ and $\mathrm{Fr}$ remained on a high level longer than that of $\mathrm{Ay}$ and $\mathrm{Fc}$. The heritability estimates of $\mathrm{Ay}$ and $(\mathrm{Fr})$ were .23 (.61) for carcass weight, .39 (.77) for net growth, .14 (.15) for carcass score and $.06(.26)$ for fatness score. Differencies between farms within feed type consisted of about $50 \%$ of the variation in growth rate and carcass weight, and about $25 \%$ in carcass scores. Feeding was more consistent on farms with mere indoor feeding than on farms where the animals were also kept on pasture.
\end{abstract}

\section{Introduction}

Beef production in Finland is mainly based on calves from dairy herds. In 1982 there were about 680000 dairy cows and 8000 beef cows in the country. At the same time about 160000 calves were delivered from dairy to other herds for fattening for beef. Half of the beef from young cattle slaughtered at slaughterhouses was obtained from farms rearing delivered calves.

The growth potential and carcass characteristics of young cattle and factors affecting them have been studied at the Experimental Stations since 1960, at the Performance Testing Stations since 1966, and on data collected from practice (e.g. VARO 1969, LINDSTRÖM \& MAIJALA 1970, MAIJALA 1972, KOSSILA \& LAMPILA 1974, RUOHOMÄKI 1981, OJALA 1982). In practice the data were collected from milk recording farms and farms specializing in fattening calves.

Experiments on the beef producing farms were started in 1969 by the Institute of Animal Breeding, Agricultural Research Centre, in cooperation with the organizations of the field and some private farms. The trials, carried out in relatively large units, were expected to give more reliable data for e.g. 
comparing genetically different groups than material collected from dairy herds, where beef production is often occasional and the number of fattened animals is small.

The purpose of the present study was to investigate in practical circumstances the differencies and variation in growth rate and carcass quality in different breed groups under varying conditions, the genetical and environmental factors affecting growth rate and carcass quality of beef animals, and to get practical experience for developing beef recording systems.

\section{Material and methods}

The material consisted of beef production data of 4209 animals on 179 farms in different parts of the country. The data were collected in 1971-76 from field experiments carried out by the Institute of Animal Breeding, Agricultural Research Centre, in cooperation with the slaughterhouse and extension organizations as well as the A. I. societes, and in 1974-77 from beef records kept by the Finnish Animal Breeding Association.

By composition the material corresponded with the average commercial calf material: by sex $90 \%$ were bulls and $10 \%$ heifers; by breed of sire $70 \%$ were Ayrshire (Ay), $20 \%$ Friesian (Fr), $5 \%$ Finncattle (Fc), 4 \% Charolais $(\mathrm{Ch})$, and less than $1 \%$ Hereford $(\mathrm{Hf})$ and Aberdeen Angus (Ab). The samples were divided according to the breed division in the A. I. statistics (ANON. 1970 and 1976).

Most farms acquired the calves at the age of 2 weeks through slaughterhouses, while some obtained them directly from neighbours or from their own herd. The calves were marked with a numbered plastic ear mark and data from birth till slaughterhouse were collected on a beef recording card. The data were computed at the Institute of Animal Breeding using programs planned for the on-farm test and library programs. The results were reported to the farms and organizations involved.

The country was divided into four areas according to the coverage of the co-operative slaughterhouses (Fig. 1). About half of the samples were from Area 2.

\section{Rearing}

Rearing plans were recorded in outline. On most farms feeding was based on green silage fodder with some domestic concentrates. On some farms the animals were also kept on pasture. In order to eliminate the effect of feeding in the analysis of growth performance, the farms were divided into five feed types (KENTTÄMIES 1974 and 1975) by main fodder and intensity of feeding. The feed types were defined as follows:

1) Green line feeding (silage, pasture, some concentrates)

2) Scanty feeding (both roughage and concentrates less than needed) 
Fig. 1. Areas covered by the co-operative slaughterhouses.

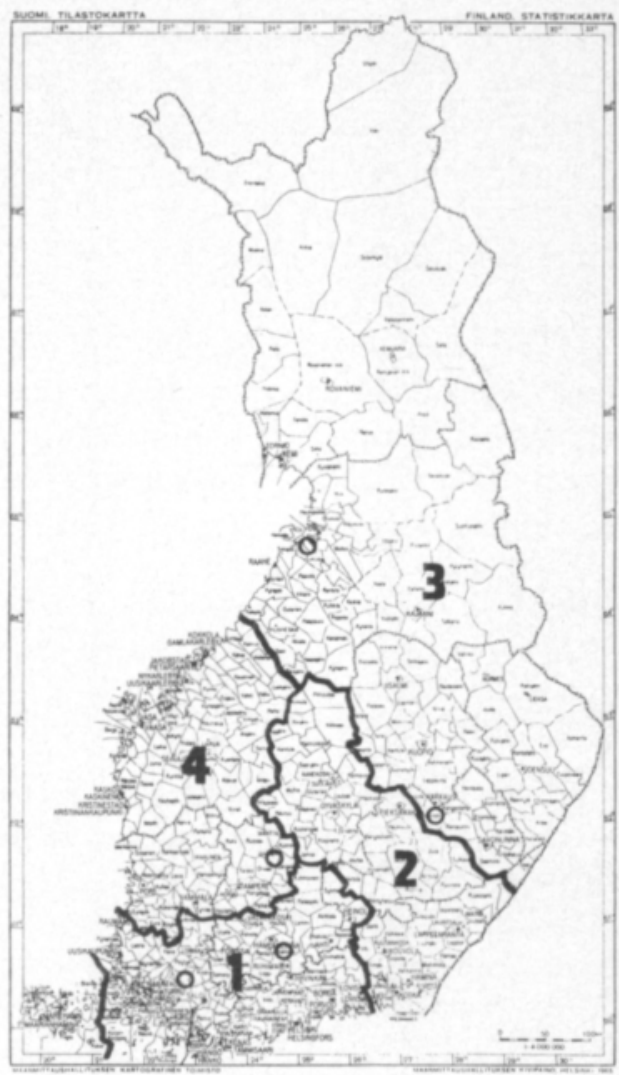

3) Standard feeding (silage, concentrates $40-60 \%$ of f.u.)

4) Intensive feeding (silage, concentrates $60-80 \%$ of f.u.)

5) Hay feeding (hay, pasture, concentrates)

Feed type was recorded for $3 / 4$ of the animals. More than half of the animals were included in the group standard feeding (type 3 ), one third in the roughage feed types including pasture (1 and 5), $11 \%$ in intensive feeding (4) and $7 \%$ in scanty feeding (2).

Rearing time varied between 219-599 days, partly because of feed type and partly because of some other farmdependent factor. The animals were divided into two age groups. There were approximately the same number of animals in each group (219-419 vs. 420-599 d). In the two age groups the animals were divided equally by breed, with the exception that there were 1.5 times more Friesians in the older than in the younger age group. In the feed type green line feeding the animals were more often included in the older than in the younger group.

The traits to be studied were

rearing time, $d$ (interval between transport or the age of $14 \mathrm{~d}$ till slaughter) carcass weight, $\mathrm{kg}$

net growth, g/d (carcass weight $-0.5 \times$ calf weight divided by rearing time) 
carcass quality, scores (total, fatness)

Prior to certain analyses the carcass weights were corrected to a certain age by using individual net growth.

\section{Comparison of breeds}

The breeds were compared by breed of sire within farms using simultaneously reared animals. Ayrshire breed was used as control on each farm. The results were calculated within year or half a year as relative estimates from the age corrected values. The relative estimates were weighted with the number of animals using the formula (e.g. MASON 1957):

$$
\begin{aligned}
\frac{\mathrm{n} 1 \times \mathrm{n} 2}{\mathrm{n} 1+\mathrm{n} 2}, \text { where } \mathrm{n} 1 & =\text { number of animals to be compared } \\
\mathrm{n} 2 & =\text { number of control animals }
\end{aligned}
$$

Estimation factors affecting the traits

In order to estimate the main factors affecting slaughter traits the material was analyzed by the least squares analysis (HARVEY 1970) using the following three models:

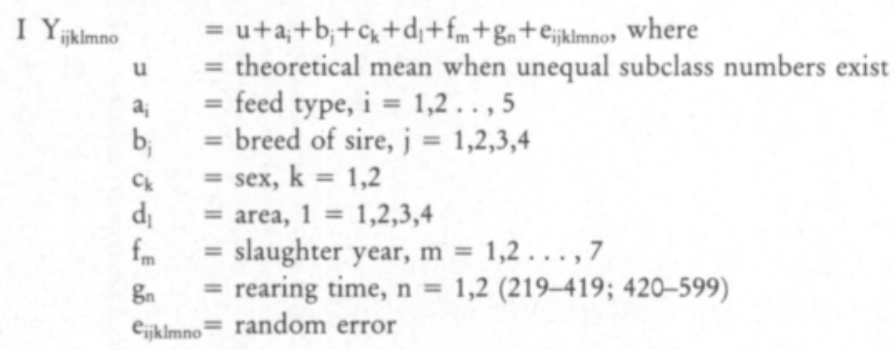

The effects of farm were estimated using the following model:

$$
\text { II } \begin{aligned}
\mathrm{Y}_{\mathrm{i} i \mathrm{klmno}} & =\mathrm{u}+\mathrm{a}_{\mathrm{i}}+\mathrm{t}_{\mathrm{ij}}+\mathrm{b}_{\mathrm{k}}+\mathrm{c}_{1}+(\mathrm{bc})_{\mathrm{kl}}+\mathrm{d}_{\mathrm{m}}+\mathrm{f}_{\mathrm{n}}+\mathrm{e}_{\mathrm{ijk} \text { mno }}, \text { where } \\
\mathrm{t}_{\mathrm{ij}} & =\text { effect of farm within feed type, } \mathrm{j}=1 \ldots 188 \\
\mathrm{bc} & =\text { interaction between breed and sex }
\end{aligned}
$$

Other terms were as in Model I, except that the effect of rearing time is missing. Prior to the analyses carcass weight was corrected to the average age of the material.

The effects of sire were analyzed by breed using the following model:

$$
\text { III } \begin{aligned}
Y_{\text {iiklmno }} & =u+a_{i}+s_{j}+c_{k}+d_{1}+f_{m}+g_{n}+e_{i j k l m n o} \text {, where } \\
s_{j} & =\text { effect of sire, } j=1 \ldots 174(A y), 1 \ldots 62(\mathrm{Fr}) ; \text { other terms as in Model I. }
\end{aligned}
$$

The terms t, vs and e were considered random, other terms fixed.

Before analyzing the effects of sire, the material was discarded to include min. 4 progeny/sire. Rearing time was divided into four groups (219-329, $330-419,420-499$, and 500-599 d). As the number of animals in the analyses 
by breed had become smaller, some groups within terms were combined: Feed type was divided into four groups consisting of roughage feeding (types 1 and 5), scanty feeding (2), concentrate feeding (3 and 4), and feeding unknown. In the term slaughter year the first and the second class were united. In the term area there was an additional fifth class including animals of Ay breed with area unknown.

The standard error of the heritability estimate was estimated using the formula of ROBERTSON (1959):

s.e. $h^{2}=\left(h^{2}+\frac{4}{n}\right) \sqrt{2 / N}$, where

$\mathrm{N}=$ number of sires, $\mathrm{n}=$ number of progeny $/$ sire

\section{Results and discussion}

Means

In the study, the mean rearing time was $432 \mathrm{~d}$, carcass weight $187 \mathrm{~kg}$, and net growth $389 \mathrm{~g} / \mathrm{d}$ (Table 1). Rearing beef animals was more efficient on specialized farms than in milk recording herds (MAIJALA 1972). The traits studied included a lot of variation: the coefficient of variation (c.v.) was $20 \%$ for rearing time, $21 \%$ for carcass weight, and $22 \%$ for net growth. Similarly, in field experiments in Norway the c.v. was $18 \%$ for age corrected carcass weight after eliminating the effects of systematic factors (GRAVIR 1977).

By feed type the c.v. was the highest for scanty and hay feeding (28$30 \%$ ) and the lowest for intensive feeding (16\%). By age group the range of variation was similar. By breed within age group the c.v. for the traits of $\mathrm{Fc}$ bulls slaughtered at an age under $420 \mathrm{~d}$ was higher than of those slaughtered at an older age. The reverse was found for the other breeds. Differencies in variation of net growth and carcass weight may be a consequence of different growth curves of the breeds (Fig. 5).

Table 1. Means and standard deviations of the traits.

\begin{tabular}{lcrr}
\hline Trait & $\mathrm{N}$ & Mean & S.D. \\
\hline Rearing time, d & 4209 & 431.6 & 86.7 \\
Carcass weight, kg & 4209 & 186.9 & 39.2 \\
Net growth, g/d & 4209 & 388.6 & 84.5 \\
Carcass score $^{1)}$ & 4067 & 8.4 & .8 \\
Fatness score $^{2)}$ & 3807 & 4.0 & .4 \\
\hline
\end{tabular}

1) Carcass score: $7=\mathrm{I}-, 8=\mathrm{I}, 9=\mathrm{I}+, 10=\mathrm{E}, 11=\mathrm{E}+$

${ }^{2}$ ) Fatness score: $3=\mathrm{C}, 4=\mathrm{A}, 5=\mathrm{T}$ 
Net growth and carcass traits were significantly affected by feed type, breed of sire, slaughter year, area, sex, and age group, except the effect of feed type on total scores and the effect of breed of sire on fatness scores (Table 2). The factors mentioned above, except breed of sire, significantly affected also rearing time (age group not included in the model).

Year and area

In 1971-77 the carcass weight grew by $40 \mathrm{~kg}$. This was mainly due to the longer rearing time and improved efficiency of rearing. Due to the government's measures it has become more profitable to grow the animals heavier than earlier. In addition, the growth potential of calves has been improved by selection of performance tested A.I. bulls as well as by the wider use of beef bulls on dairy cows for producing calves for beef production.

The differencies between areas may be caused by several feed-dependent factors. Further, the activities of the slaughterhouse and extension organizations have varied in advising beef production. During the study the differencies between areas grew somewhat smaller.

\section{Feed type}

According to several studies an adequate supply of energy is the most important factor affecting meat yield (e.g. WITT et al. 1971, KOSSILA \& LAMPILA 1974, POUTIAINEN \& TUORI 1974, RICHARDSON 1979). In spite of a shorter rearing time the carcass weights were higher on feeding based on concentrates (types 3 and 4 ) than on roughage and pasture (1 and 5, Table 2). This may be caused more by the differencies in intensity of feeding than in rearing time. The proportion of concentrates was higher on farms fattening animals indoors than keeping the animals also on pasture. The growth rate was increasing with the intensity of feeding also when the fattened animals were kept indoors. The animals became more fatty on scanty (2) and hay (5) feeding than on intensive (4) feeding. However, the differencies between feed types in age corrected carcass weights varied a little and increased with age (Fig. 2). The results are in good agreement with results from experiments (KOSSILA \& LAMPILA 1974, POUTIAINEN \& TUORI 1974).

Breed of sire

The growth potential of large beef and dual purpose breeds has exceeded that of the smaller breeds (e.g. LINDHE 1968, LIBORIUSSEN 1978, RUOHOMÄKI 1981). Similarly, in the present study the $\mathrm{Ch}$ crossbreds had on average the best growth rate and carcass quality and were followed by $\mathrm{Fr}, \mathrm{Ay}$ 
Table 2. Effect of factors influencing the carcass traits. Least squares constants and significance of F-values.

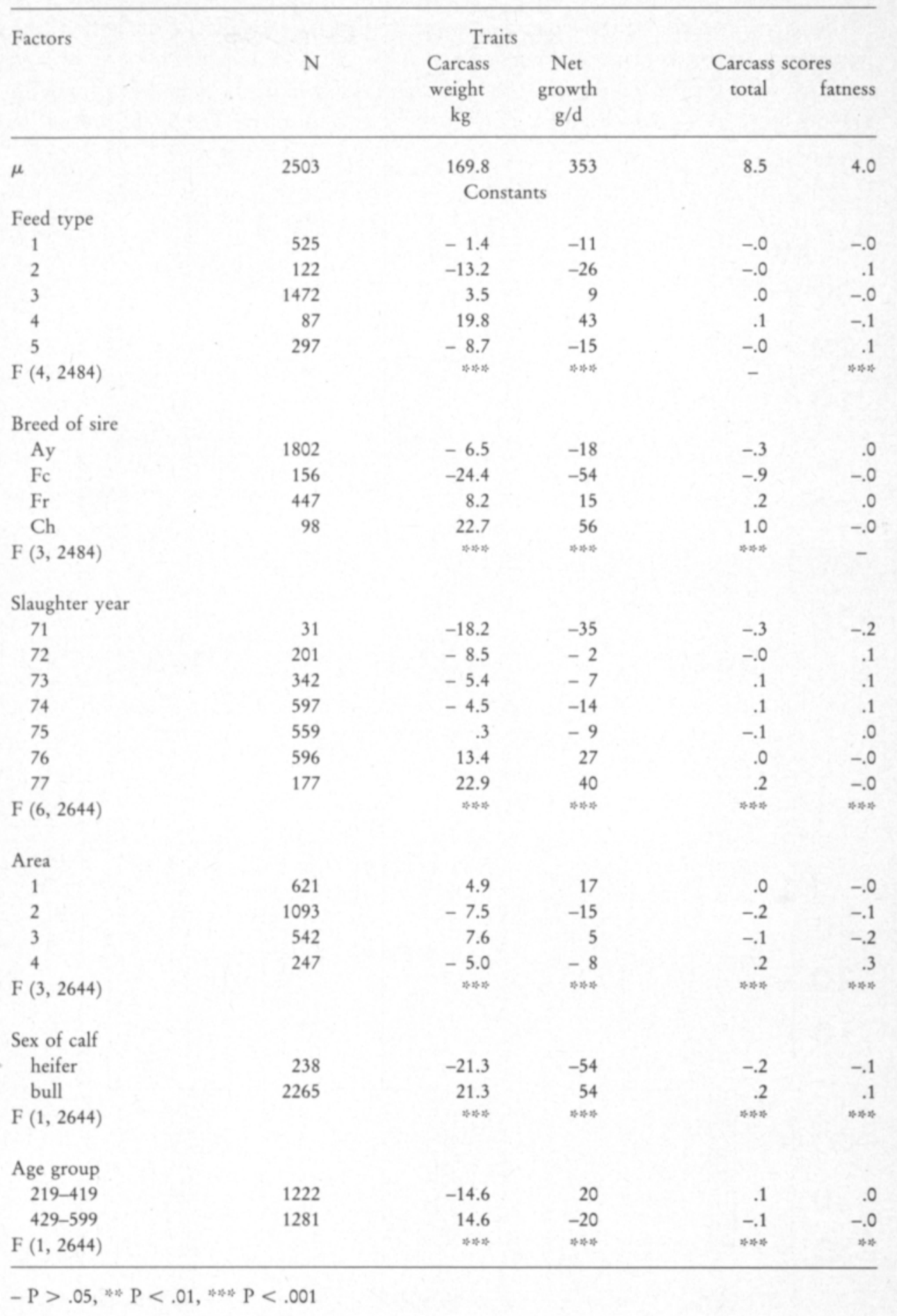


and $\mathrm{Fc}$ (Tables 2 and 3 ). The order was the same in each feed type, age group and sex. The $\mathrm{Ch}$ crossbred bulls were 16 and $\mathrm{Fr}$ bulls $11 \%$-units heavier but Fc bulls $7 \%$-units lighter than the contemporary Ay bulls. The differencies between heifers were still larger.

The interaction between breed of sire and feed type was significant in rearing time, net growth and carcass weight corrected for the average rearing

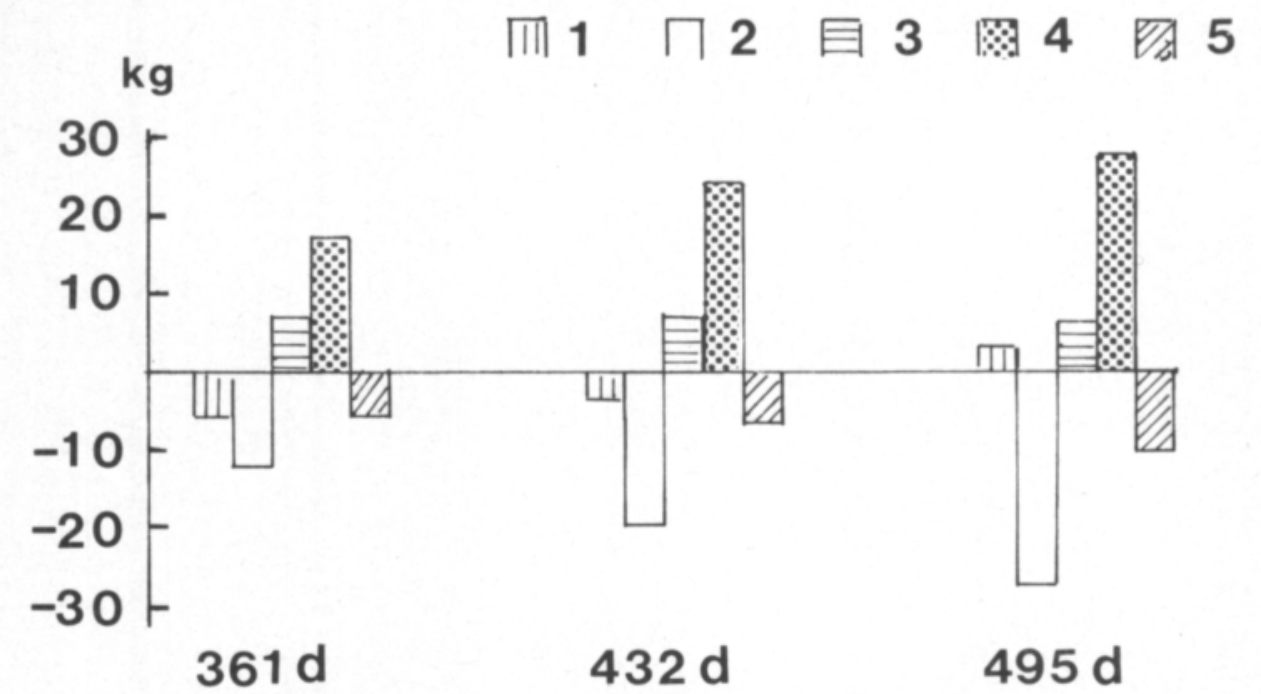

Fig. 2. Differencies between feed types in carcass weight corrected for the average rearing time of the whole material and of each age group. Least squares constants. Effects of breed, sex and year have been eliminated. $\mathrm{N}=2662$.

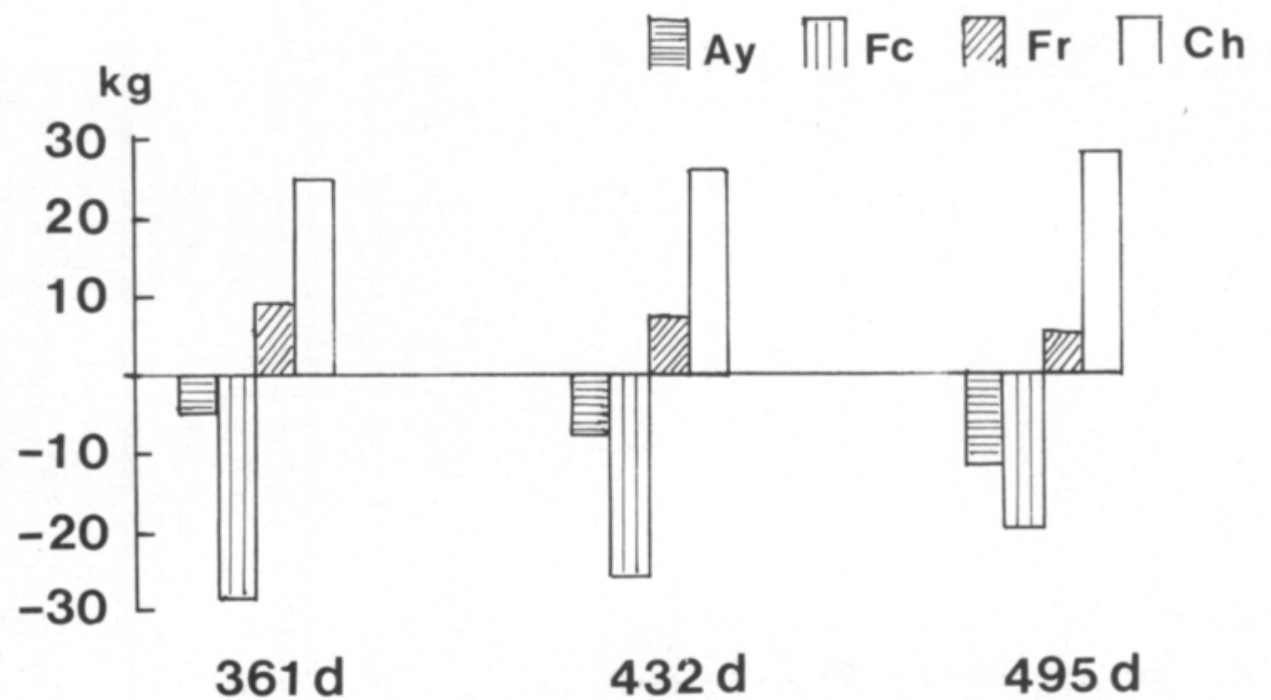

Fig. 3. Differencies between breeds in carcass weight corrected for the average rearing time of the whole material and of each age group. Least squares constants. Effects of feed type, sex and year have been eliminated. $\mathrm{N}=2662$. 
Table 3. Carcass weight and net growth of the different breeds. $A y=100 . n_{1}=$ number of $A y$ animals, $n_{2}$ $=$ number of animals of other breeds.

\begin{tabular}{|c|c|c|c|c|c|c|c|c|}
\hline \multirow{2}{*}{$\begin{array}{l}\text { Breed } \\
\text { of } \\
\text { sire }\end{array}$} & \multicolumn{4}{|c|}{ Bulls } & \multicolumn{4}{|c|}{ Heifers } \\
\hline & $\mathrm{n}_{1}$ & $\mathrm{n}_{2}$ & $\begin{array}{c}\text { Carcass } \\
\text { weight }\end{array}$ & $\begin{array}{c}\text { Net } \\
\text { growth }\end{array}$ & $\mathrm{n}_{1}$ & $\mathrm{n}_{2}$ & $\begin{array}{r}\text { Carcass } \\
\text { weight }\end{array}$ & $\begin{array}{c}\text { Net } \\
\text { growth }\end{array}$ \\
\hline Ay & & & 100 & 100 & & & 100 & 100 \\
\hline $\mathrm{Fc}$ & 596 & 143 & 93 & 93 & 32 & 5 & 86 & 85 \\
\hline $\mathrm{Fr}$ & 1434 & 413 & 111 & 112 & 65 & 33 & 115 & 117 \\
\hline $\mathrm{Ch}$ & 883 & 106 & 116 & 117 & 69 & 24 & 127 & 130 \\
\hline Hf & 112 & 7 & 102 & 103 & & & & \\
\hline $\mathrm{Ab}$ & 65 & 7 & 100 & 104 & & & & \\
\hline
\end{tabular}

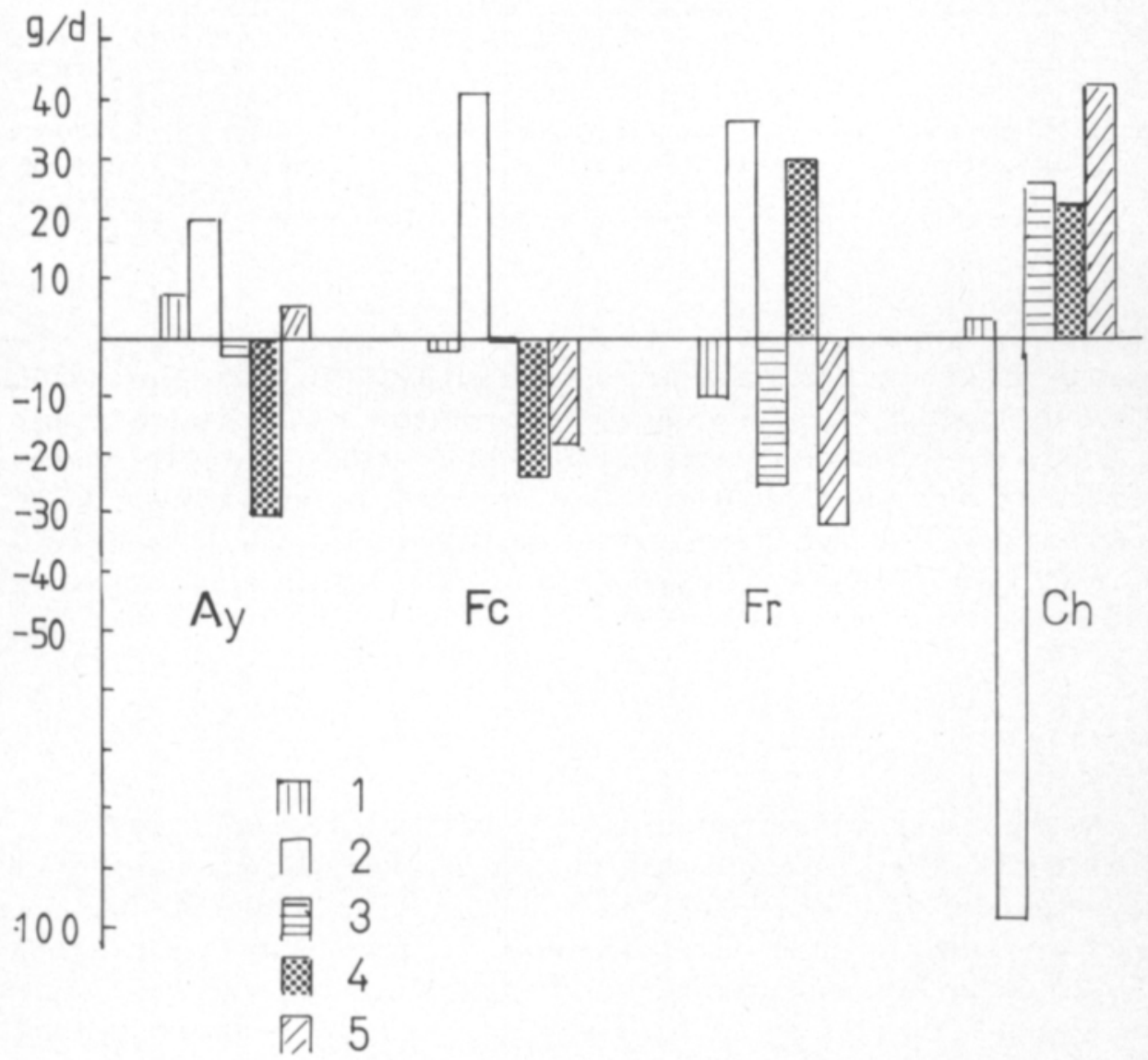

Fig. 4. Interaction between breed and feed type in net growth of the bulls. Least squares constants. Effects of breed, feed type, year, area and age group have been eliminated. $\mathrm{N}=2125$.

time of each farm. This may partly be due to the dissimilar appetite and rouhage conversion rate of the breeds. The Ay bulls grew relatively best on feeding based on rouhage or on fodder of low quality (Fig. 4). However, on feeding based on concentrates the Ay bulls did not manage as well. The Fc bulls grew relatively best on scanty feeding, while the Ch bulls suffered 


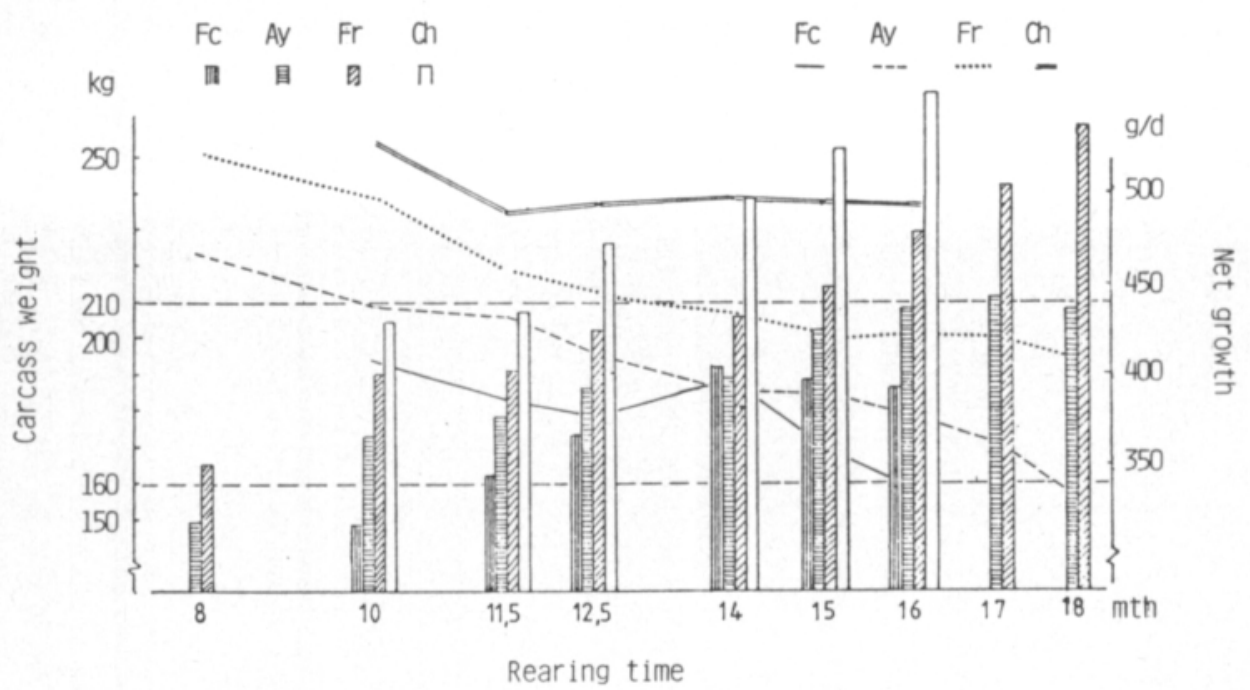

Fig. 5. Net growth rates and carcass weights of bulls of different breeds slaughtered at different ages. Animals were fattened indoors. $\mathrm{N}=2064$.

clearly of the inadequate supply of feed. Lack of energy may often restrict the growth rate of large breeds in practical rearing (HOCKING \& BOWMAN 1979). Matching the feed resources with the obtained breeds is often hard to arrange in production based on delivered calves. On the other hand it is easier to regulate rearing time. Differencies between breeds became larger with age (Fig. 3 and 5). The high growth rate of the large breeds (Ch, Fr) continued longer than that of the small breeds ( $\mathrm{Ay}, \mathrm{Fc})$. The benefits of crossbreeding will increase with age (PABST 1977).

Sex of calf

As the results from experiments (e. g. POUTIAINEN and TUORI 1974, RUOHOMÄKI 1981) have indicated, the growth rate and carcass quality of bulls exceeded those of heifers (Tables 2 and 4). The differencies between sexes were slightly larger than those found in experiments (RUOHOMÄKI 1981). Like in these experiments, the differencies between sexes were larger for $\mathrm{Ay}$ and $\mathrm{Fr}$ than for $\mathrm{Ch}$ and $\mathrm{Fc}$. The interaction between breed of sire and sex of calf was significant neither in carcass weight nor in net growth. In addition to differencies in growth rate the differencies in carcass weight may have been affected by the lighter calf weight and the lower dressing percentage of heifers (e.g. LINDHE 1968, PABST 1977, RUOHOMÄKI 1980 b). Differencies between sexes increased with age (Fig. 6). This may partly be due to the differencies in rearing time as growth rate grew less with age. In the younger age group the heifers were slaughtered $20 \mathrm{~d}$ younger, whereas in the older age group $45 \mathrm{~d}$ older than the bulls. Perhaps some of the dairy heifers were originally not intended for beef production. 
Table 4. Carcass weight and net growth of the bulls as compared to the heifers of the same breed. Heifers $=100 . n_{1}=$ number of heifers, $n_{2}=$ number of bulls.

\begin{tabular}{lrrcc}
\hline Breed of sire & $n_{1}$ & $n_{2}$ & Carcass weight & Net growth \\
\hline Heifers & & & 100 & 100 \\
Bulls & & & & \\
Ay & 250 & 766 & 134 & 141 \\
Fc & 12 & 29 & 121 & 125 \\
Fr & 62 & 151 & 139 & 146 \\
Ch & 27 & 35 & 129 & 133 \\
\hline
\end{tabular}

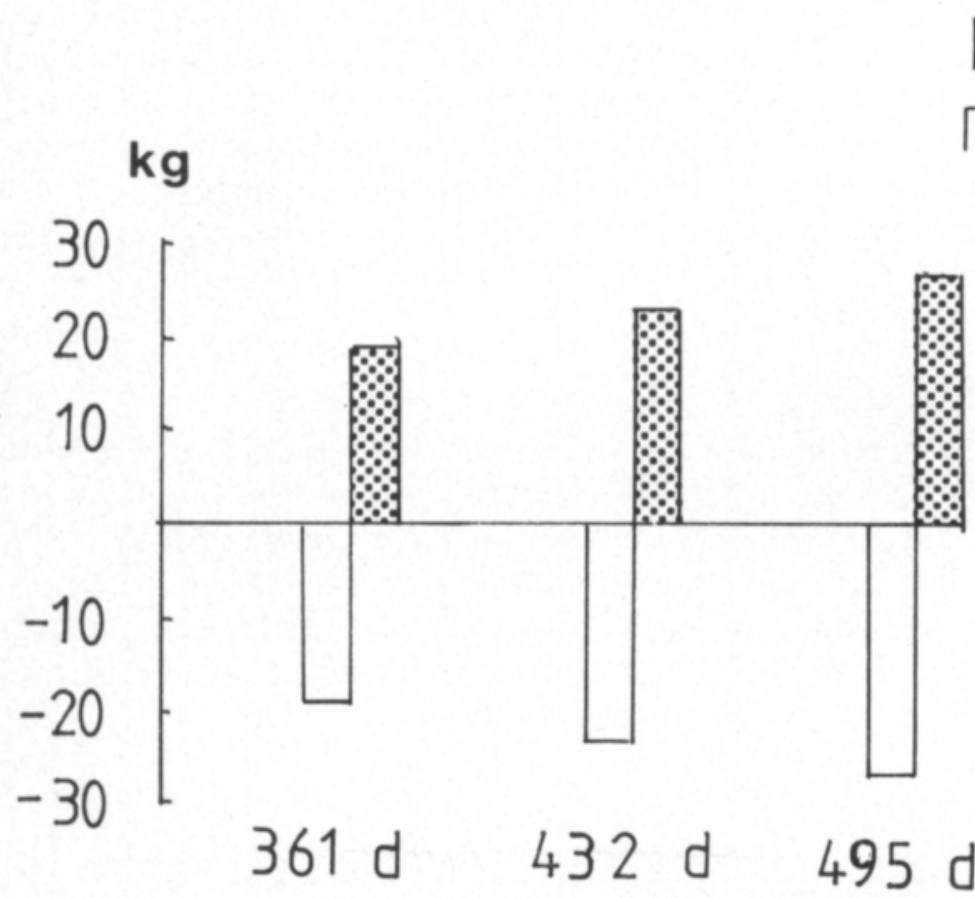

Fig. 6. Differencies between heifers $(\mathrm{H})$ and bulls $(\mathrm{B})$ in carcass weight corrected for the average rearing time of the whole material and of each age group. Least squares constants. Effects of feed type, breed and year have been eliminated. $\mathrm{N}=2662$.

Farm

The most important factor affecting growth rate was the farm. In growth rate and carcass weight the variation between farms within feed type corresponded for about $50 \%$ of the total variation and in carcass scores for about $25 \%$ (Table 5). According to preliminary analyses there was more variation between farms in feed types based on rouhage and pasture (types 1 and 5) than on concentrates ( 3 and 4$)$. The share of farm of the total variation was 
Table 5. Composition of variance, and proportion of farm for carcass traits. $\mathrm{N}=2603$.

\begin{tabular}{|c|c|c|}
\hline Trait & Composition of variance & Share of farm, \% \\
\hline Carcass weight (432 d) & $498.3+11.8 \times 468.7$ & 48.5 \\
\hline Rearing time & $3394.4+11.8 \times 3541.8$ & 51.1 \\
\hline Net growth & $2546.5+11.8 \times 2422.0$ & 48.8 \\
\hline Carcass score & $.46+11.8 \times \quad .16$ & 25.9 \\
\hline Fatness score & $.15+11.8 \times \quad .06$ & 27.3 \\
\hline
\end{tabular}

$50 \%$ in carcass weight and $53 \%$ in net growth in feed types 1 and 5, and $41 \%$ and $42 \%$ in feed types 3 and 4 , resp. The data included the present material and results of data collected in 1972-1980. On feeding based on rouhage there were 894 bulls, on average 20,4 animals/farm, and on feeding based on concentrates 2064 bulls, on average 35.4 animals/farm. By drawing production plans for each farm and by recording the results the differencies between farms could be reduced. In this way the efficiency of beef production could be improved.

Sire

In addition to the considerable environmental effects on net growth and carcass traits, there were also genetical differencies between the progenies of A.I. bulls (Tables 6 and 7). The heritabilities for carcass weight of Ay were similar to the results from dairy recording herds of MAIJALA (1972) and GRAVIR (1977) as well from the experiment of RUOHOMÄKI (1980 a).

Concerning the heritabilities for net growth and carcass weight there were inter-breed differencies. There may have been differencies in selection

Table 6. Composition of variance, and heritability estimates for carcass traits of $\mathrm{Ay} . \mathrm{N}=1235$.

\begin{tabular}{|c|c|c|}
\hline Trait & Composition of variance & Heritability \\
\hline Carcass weight & $762.3+6.8 \times 45.9$ & $.23 \pm .09$ \\
\hline Net growth & $3749.1+6.8 \times 399.8$ & $.39 \pm .10$ \\
\hline Carcass score & $.45+6.8 \times \quad .02$ & $.14 \pm .08$ \\
\hline Fatness score & $.158+6.8 \times \quad .003$ & $.06 \pm .07$ \\
\hline
\end{tabular}

Table 7. Composition of variance, and heritability estimates for carcass traits of $\mathrm{Fr} . \mathrm{N}=453$.

\begin{tabular}{|c|c|c|}
\hline Trait & Composition of variance & Heritability \\
\hline Carcass weight & $659.1+6.6 \times 125.1$ & $.61 \pm .18$ \\
\hline Net growth & $3263.3+6.6 \times 776.2$ & $.77 \pm .25$ \\
\hline Carcass score & $.58+6.6 \times \quad .02$ & $.15 \pm .13$ \\
\hline Fatness score & $.17+6.6 \times \quad .01$ & $.26 \pm .15$ \\
\hline
\end{tabular}


intensity of the performance tested bulls within the breeds. However, as the number of progeny/sire was small, environmental effects like the variable distribution of breeds in age classes or feed types, may have influenced the differencies between heritabilities. However, it seems possible to increase by selection the growth rate and carcass quality of our breeds, as well as by improving the rearing circumstances.

\section{Summary}

Variation in growth rate and carcass quality and factors affecting the traits were studied on farms rearing delivered calves.

The material consisted of 4209 animals on 179 farms in different parts of the country. The data were collected in 1971-77. By composition the material corresponded with the average commercial calf material. On most farms feeding was based on green silage fodder with some domestic concentrates. On some farms the animals were also kept on pasture. Rearing time varied between 219-599 days.

The mean rearing time was $432 \mathrm{~d}$, carcass weight $187 \mathrm{~kg}$, and net growth $389 \mathrm{~g} / \mathrm{d}$.

Net growth and carcass traits were significantly affected by feed type, breed of sire, slaughter year, area, sex, and rearing time. During the study the carcass weight increased by $40 \mathrm{~kg}$. Differencies between areas grew somewhat smaller. The carcass weights were higher on feeding based on concentrates than on rouhage and pasture, in spite of shorter rearing time.

The $\mathrm{Ch}$ crossbreds had on average the best growth rate and carcass quality and were followed by Fr, Ay and Fc. The order was the same in each feed type, age group and sex. The Ch crossbred bulls were 16 and Fr bulls 11 $\%$-units heavier but $\mathrm{Fc}$ bulls $7 \%$-units lighter than the contemporary Ay bulls. Differencies between heifers were still larger. The Ay bulls grew relatively best on freeding based on rouhage or on fodder of low quality. The Fc bulls grew relatively best on scanty feeding, while the $\mathrm{Ch}$ bulls suffered clearly of the inadequate supply of feed. The high growth rate of the large breeds ( $\mathrm{Ch}, \mathrm{Fr}$ ) continued longer than that of the small breeds ( $\mathrm{Ay}, \mathrm{Fc}$ ).

Growth rate and carcass quality of bulls exceeded those of heifers. Differencies between sexes were larger for $\mathrm{Ay}$ and $\mathrm{Fr}$ than for $\mathrm{Ch}$ and Fc. Differencies between sexes increased with age.

The heritability estimates of $\mathrm{Ay}$ and ( $\mathrm{Fr}$ ) were .23 (.61) for carcass weight, .39 (.77) for net growth rate, .14 (.15) for carcass score and .06 (.26) for fatness score. It seems possible to increase by selection the growth rate and carcass quality of our breeds, as well as by improving the rearing circumstances.

The most important factor affecting growth rate was the farm. In growth rate and carcass weight the variation between farms within feed type corresponded for $50 \%$ of the total variation, and in carcass scores for about $25 \%$. Feeding was more consistent on farms with mere indoor feeding than on farms where the animals were also kept on pasture. By drawing production 
plans for each farm and by recording the results the differencies between farms could be reduced. In this way the efficiency of beef production could be improved. In addition, beef recording data could be used for progeny testing of A.I. bulls to confirm the results obtained from performance testing.

Acknowledgments. I wish to express my gratitude to every person, farm and organization involved in the beef production experiments in field carried out by the Institute of Animal Breeding, Agricultural Research Center. Especially I wish to thank Prof. Kalle Maijala for the initiation and planning of the experiments.

Economically the work was supported by the Academy of Finland and the August Johannes and Aino Tiura Agricultural Research Foundation.

\section{Literature}

ANON. 1970 ja 1976. Keinosiemennysyhdistysten Liitto ry:n vuosikertomukset vuosilta 1970 ja 1976.

GRAVIR, K. 1977. Opplegg og erfaring med feltmessig avkomsgranskning for kjott i Norge. Nordiskt Symposium kring individprovningsfrågor, Helsingfors 13.-14. 9. 1977. $10 \mathrm{p}$.

HARVEY, W R. 1970. Estimation of variance and covariance components in the mixed model. Biometrics 26: 485-504.

HOCKING, P. M. \& BOWMAN, J. C. 1979. Genotype-environment interaction for beef production in a breed evaluation trial. British Society of Animal Production, Harrogate 19.-21. 3. 1979. Summary Anim. Prod. 28: 459.

KENTTÄMIES, H. 1974. Teurasnaudan kasvukokeet yksityisillä tiloilla. Kehittyvä Maatalous 18: 16-24.

- 1975. Ruokintatyypin vaikutus lihanaudan kasvuun yksityisillä tiloilla suoritetuissa kokeissa. Laudaturtyö. 62 p.

KOSSILA, V. \& LAMPILA, M. 1974. Naudanlihan tuotanto vihreällä linjalla. Kehittyvä Maatalous 19: 20-38.

LIBORIUSSEN, T. 1978. Brukskrydsning i SDM og RDM. En sammenlignende undersogelse af otte kod- og kombinationsracers egnethed. 466. Beretn. fra Statens Husdyrbruksforsog. 123 p.

LINDHE, B. 1968. Crossbreeding for beef with Swdish Red and White cattle. Part I. Performance under varying field conditions. Lantbr.högsk. Ann. 34: 465-515.

LINDSTRÖM, U. \& MAIJALA, K. 1970. Evaluation of performance test results for A.I. bulls. Acta Agric. Scand. 20: 207-218.

MAIJALA, K. 1972. Sonnien monipuolinen jälkeläisarvostelu II. Karjatalous 48 (11): 480-483.

MASON, I. L. 1957. Der Vergleich gleichzeitiger, gleichaltiger Stallgefährten (Conttemporary Comparison). Z. Tierzüchtg. Züchtgsbiol. 70: 339-347.

OJALA, M. 1982. Vanhempien tuotantotietojen ja eräiden ympäristötekijöiden yhteys sonnien kasvukoetuloksiin. Kotieläinjalostuksen tiedote no. 55, 54 p.

PABST, W. 1977. Praxisübliche Wirtschaftsmast von männlichen und weiblichen Einfachgebrauchskreuzungen auf der Grundlage Deutsches Braunvieh und Deutsche Schwarzbunte. 3. Göttinger Tagung "Rindfleischerzeugung" 21./22. April 1977, pp. 32-52. Ed. Langholz, H.-J. \& Pabst, W.

POUTIAINEN, E. \& TUORI, M. 1974. Hiehojen, härkien ja sonnien lihantuotannon vertailua. Kehittyvä Maatalous 19: 48-55.

RICHARDSON, F. D. 1979. Some nutritional factors influencing the growth and efficiency of beef cattle at different ages and their implications for the design of regimes for the performance testing of young bulls; a review. Rhod. J. agric. Res. 17: 71-87.

ROBERTSON, A. 1959. Populationsgenetik und quantitative Vererbung. Handbuch der Tierzüchtung 2: 77-104. Hamburg und Berlin.

RUOHOMÄKI, H. 1980 a. Painavien ja kevyiden ayrshiresonnien poikaryhmät lihantuotantokokeissa. Lihanautakokeiden tuloksia IV. Kotieläinjalostuksen tiedote no 40: 1-14.

- 1980 b. Rotu- ja sukupuoliryhmien teuraspainojen ja teurasprosenttien vertailu lihantuotan- 
tokokeissa. Lihanautakokeiden tuloksia IV. Kotieläinjalostuksen tiedote no 40: 15-23.

- 1981. Lihakarjakokeet vuosina 1960-1980. Kotieläinjalostuksen tiedote no 46, 30 p.

THIESSEN, R. B. 1978. Breed variation - growth and food efficiency. The British Council Course 827.

Edinburgh-Aberdeen 7.-20. 5. 1978. Erip. 6 p.

VARO, M. 1969. Ruhon laadun arvioimismenetelmistä elävistä ja teurastetuista naudoista. EAAP Helsinki 23.-26. 6. 1969. Erip. 16 p.

WITT, M., ANDREAE, U. \& KALLWEIT, E. 1971. Einfluss unterschiedlicher Fütterungsintensität auf Wachstum und Fettansatz beim Rind, untersucht an eineiigen Zwillingsbullen. Z-kunde 43: 173186.

Ms received December 31, 1983

\section{Lihanaudan teurasominaisuuksiin vaikuttavia perinnöllisiä ja ulkoisia tekijöitä kenttäkokeissa}

\section{Hilkka Kenttämies}

\section{Helsingin yliopisto, kotieläinten jalostustieteen laitos}

Lihanaudan kasvunopeuden ja teuraslaadun vaihtelua sekä niihin vaikuttavia tekijöitä tutkittiin Maatalouden tutkimuskeskuksen kotieläinjalostuslaitoksen kenttäkokeista ja Suomen Kotieläinjalostusyhdistyksen tarkkailusta vuosina 1971-77 kertyneiden teurastulosten pohjalta. Aineisto käsitti 4209 eläintä 179 eri puolilla Suomea sijaitsevassa karjassa, jotka kasvattivat pääasiassa ostovasikoita. Eläinaines vastasi keskimääräistä välitysvasikkatasoa. Eläimiä ruokittiin useimmilla tiloilla kotoisella nurmirehulla ja viljaväkirehulla, joillakin tiloilla eläimiä myös laidunnettiin. Kasvatusaika oli 219-599 pv.

Ominaisuuksiin vaikuttavia tekijöitä tutkittiin varianssianalyysillä pienimmän neliösumman menetelmää käyttäen. Eri rotuja ja sukupuolia verrattiin samalla tilalla samanaikaisesti kasvatettujen eläinten kesken.

Keskimääräinen kasvatusaika oli 432 pv, teuraspaino $187 \mathrm{~kg}$ ja nettokasvu $389 \mathrm{~g} / \mathrm{pv}$. Vaihtelukertoimet olivat vastaavasti 20,21 ja $22 \%$.

Teurasominaisuuksiin vaikuttivat tilastollisesti merkitsevästi teurastusvuosi, teurastamoalue, tilan ruokintatyyppi, eläimen ikä, sukupuoli ja rotu. Teuraspaino kohosi tutkimuksen aikana 40 kilolla, mihin vaikuttivat huomattavasti sekä kasvatusajan piteneminen että kasvatuksen tehostuminen. Alueelliset erot pienenivät jonkin verran. Kasvunopeus heikkeni eläinten vanhetessa. Sisäruokinnalla olleilla eläimillä kasvatusaika oli lyhempi, mutta teuraspaino suurempi kuin laidunnetuilla eläimillä. Ruokinnan voimakkuus vaikutti ilmeisesti enemmän teuraspainoon kuin kasvatusaika. Niukalla ja heinävaltaisella ruokinnalla olleet eläimet rasvoittuivat herkemmin kuin runsaammin ruokitut.

Charolais-risteytyksillä oli keskimäärin paras kasvunopeus ja teuraslaatu, seuraavina olivat $\mathrm{Fr}$, Ay ja Sk. Järjestys oli sama tarkasteltaessa tuloksia ruokintatyypeittäin, ikäryhmittäin ja sukupuolittain. Charolaisristeytyssonnit olivat 16 ja Fr-sonnit $11 \%$-yksikköä painavampia, mutta Sk-sonnit $7 \%$-yksikköä kevyempiä kuin vastaavat Ay-sonnit. Hiehoilla rotujen väliset erot olivat vielä suuremmat. Ay-sonnit kasvoivat suhteellisesti paremmin karkearehuvaltaisella ja niukalla kuin väkirehuvaltaisella ruokinnalla. Suomenkarja menestyi suhteellisesti parhaiten niukalla ruokinnalla, mutta $\mathrm{Ch}$-risteytykset kärsivät selvästi puutteellisesta rehun saannista. Suurten rotujen ( $\mathrm{Ch}, \mathrm{Fr})$ hyvä kasvu jatkui pitempään kuin pienten rotujen (Ay, Sk). 
Sonnit olivat nopeakasvuisempia ja teuraslaadultaan parempia kuin hiehot ja erot suurenivat eläinten vanhetessa. Sukupuolten väliset erot olivat Ay:llä ja Fr:llä suuremmat kuin Sk:lla ja Ch:lla.

Periytyvyysasteiden arvot olivat Ay:llä ja (Fr:llä) teuraspainossa .23 (.61), nettokasvussa .39 (.77), teurasarvosteluluokassa $.14(.15)$ ja rasvaisuuspisteissä .06 (.26). Rotujemme teurasominaisuuksia pystytään ilmeisesti kehittämään myös valinnan avulla sen lisäksi, että parannetaan kasvatusoloja.

Yksityisen tilan hoitotasolla oli suurin vaikutus teurasominaisuuksiin. Tilojen väliset erot ruokintatyypin sisällä käsittivät noin $50 \%$ teuraspainon ja nettokasvun sekä noin $25 \%$ teurasarvostelupisteiden kokonaismuuntelusta. Kasvatus oli yhtenäisempää tiloilla, joilla eläimet olivat pelkällä sisäruokinnalla kuin tiloilla, joilla elämiä myös laidunnettiin. Tilakohtaisilla tuotantosuunnitelmilla ja niiden seurannalla pystyttäisiin kaikissa tuotantomuodoissa vähentämään tilojen välisiä eroja sekä tehostamaan tuotantoa. Lihantuotannon tarkkailutuloksia voitaisiin lisäksi käyttää keinosiemennyssonnien jälkeläisarvosteluun varmistamaan niiden yksilöarvostelutuloksia. 